\title{
Enrichment of Cobalt Values by Dry Magnetic Separation from Low-Grade Manganese Ores of Bonai-Keonjhar Belt, Orissa
}

\author{
${ }^{1}$ P. P. Mishra, ${ }^{1}$ B. K. Mohapatra*, ${ }^{2}$ P. P. Singh \\ ${ }^{1}$ Regional Research Laboratory, Bhubaneswar, India \\ ${ }^{2}$ Utkal University, Bhubaneswar, India \\ *Corresponding Author, contact: p_geology@yahoo.co.in, patitapaban@fastmail.fm
}

\begin{abstract}
Resource potential of cobalt in India is practically negligible. Cobalt in marine manganese nodule though known since long, its report from terrestrial manganese ore is least observed. This paper reports the occurrence of cobalt in low-grade manganese ores of Bonai-Keonjhar belt, Orissa, eastern India and describes methods for its possible enrichment. Cobalt is associated with manganese minerals like lithiophorite ( CoO: 1.2\%) and cryptomelane ( CoO: 0.2\%). A feed of low-grade siliceous manganese ore containing $26 \% \mathrm{Mn}$ and $32 \% \mathrm{SiO}_{2}$ and $0.08 \%$ Co was subjected to physical beneficiation. By processing the low-grade siliceous ore on a dry belt magnetic separator, a product with $47 \% \mathrm{Mn}$ at $60 \%$ recovery could be obtained. It was observed that along with manganese the cobalt value gets enriched ( Co: $0.38 \%)$ more than four times in comparison to the feed. Some other traces like $\mathrm{Ni}, \mathrm{Cu}, \mathrm{Zn}, \mathrm{Ga}, \mathrm{Li}$ etc. also get enriched in the magnetic product. Thus, through simple dry magnetic separation a low-valued material cannot only be converted to usable product but two valuable metals can also be recovered from it.
\end{abstract}

Key Words: Orissa Manganese ore, Magnetic separation, Cobalt.

\section{INTRODUCTION}

Occurrence of cobalt in the ferromanganese nodules of present day marine basins has been studied in great detail over the last few decades by several workers all over the world [1-3]. However, only limited data is available on the distribution of cobalt in terrestrial manganese ores. Delian Fan et.al., [4] has reported the occurrence of Co in Mn-ores of Sichuan province of 
China. A worldwide review of Co-rich manganese deposits and techniques required for their development and mining has been suggested by Tetsuo [5].

During detailed investigation of the manganese ores of Bonai-Keonjhar belt of Orissa, India it was observed that the Mn-ores of this region contains appreciable quantity of trace elements in general and cobalt in particular. Cobalt in Mn-ores of this belt is found to be associated with manganese minerals like lithiophorite and cryptomelane. Presence of lithiophorite in Precambrian manganese deposits of Orissa was earlier recorded by Roy [6] and Mohapatra et.al. [7]. Cobalt in Mn-deposits from this belt was first reported by Mohapatra et al. [7].

There is no workable deposit of cobalt in India and it is considered as a strategic metal of defense importance. Cobalt is only won from the copper converter slag of different $\mathrm{Cu}$-smelting plants in India. So the Co-values in Mn-ores of this belt need to be characterized and recovered. This paper reports the presence of cobalt in Bonai-Keonjhar belt, their characterization and enrichment so as to recover two valuable metals from a low-grade siliceous manganese ore of Orissa.

\section{MATERIALS AND METHODS}

Representative samples, mostly of oolitic/nodular and spongy varieties were collected from lowgrade siliceous manganese ore deposits like Shankar, Bhoot, and Spencer from Bonai-Keonjhar belt. These were subjected to optical microscopy (Leitz make Orthoplan at RRL), XRD (Phillips Diffractometer, PW-1710 at RRL) and Electron Probe Microanalyser (EPMA, JEOL make JXA 8600 Super probe, at USIC Roorkee). For beneficiation of manganese ore, high intensity dry belt magnetic separator of type LOG 1.4 SEP operated at 50 Dc Volt and 4.17 Dc A current, suitable for fine particle separation, (supplied by Boxmag Rapid Ltd., Birmingham, England) was employed. The magnetic intensity was varied between 0.73 and $1.23 \mathrm{~T}$. Dry samples of closed size fractions were continuously fed to the belt magnetic separator by vibrating feeder at controlled rate. Magnetic products were separated by moving disc at required speed and intensity. Based on the requirement the intensity, feed rate, and gap between the belt and disc in the magnetic separator were varied. Selective elements like $\mathrm{Mn}, \mathrm{Fe}$ and $\mathrm{SiO}_{2}$ were analyzed by XRF Spectrometry on Philips (PW-1400) X-ray spectrometer with scandium and Rhodium targets using Pentaerythritol (Al, Si), Thallium Acid Pathalate (Na, Mg), Germanium (P) and Lithium Fluoride (LIF, for heavier elements) as analyzing crystals in vacuum medium. The trace elements were analyzed at NGRI, Hyderabad, India using Inductively Coupled Plasma-Mass Spectrometer (ICP-MS). The ICP-MS used was a Plasma Quad PQ1 controlled by an IBM PCXT microcomputer and associated software. Standard acid dissolution procedure was adopted for sample preparation as prescribed by Balaram, et. al. [8]. Both in-house and international ore standards of different chemical composition (NNODA-1, MNODP-1 etc.) were analyzed along with the sample for precision. 


\section{RESULTS AND INTERPREATION}

\subsection{Mineralogical Characteristics}

X-ray diffraction and optical microscopic studies are exclusively employed for mineralogical characterization of Mn-ores. X-ray diffraction pattern of Mn-ore clearly reveals the presence of lithiophorite as a major manganese mineral in oolitic/nodular and spongy types of ore (Fig. 1). Other minerals present include pyrolusite (Mn-phase) and quartz (gangue mineral). Presence of cryptomelane (Mn-phase) is also recorded in some sample.

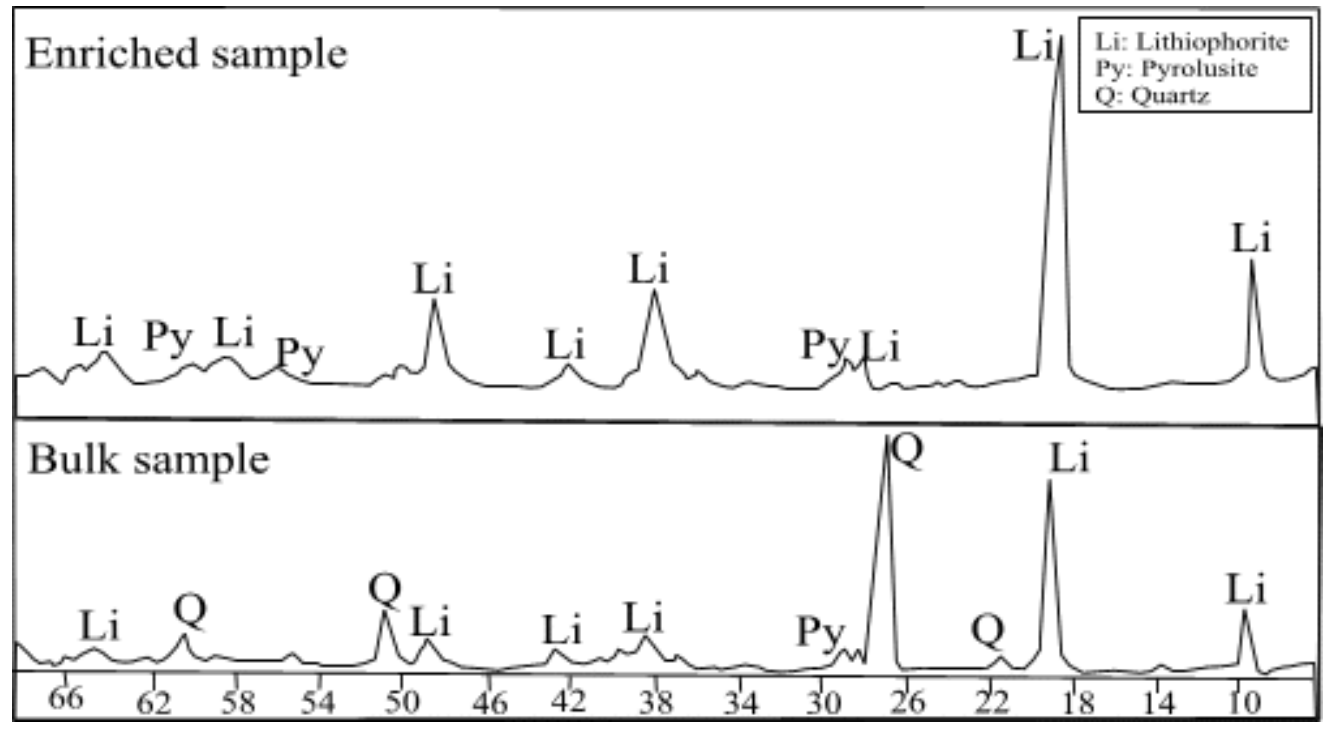

Fig. 1: X-ray diffraction pattern of feed and enriched products of low-grade siliceous Mn-ore

Lithiophorite and cryptomelane were found to contain Co values as brought out through EPMA study (Table-1). Hence, detailed characteristics of these phases were further studied under optical microscope. Lithiophorite exhibits a well-developed bireflection, from pearly gray to brownish gray and strong anisotropism, making crystallites appear black and white under crossed polar (Fig.2). The mineral has lowest VHN values (40-60) amongst its co-existing phases. The lithiophorite exhibits mamillary growth with undulose segmented twinning (Fig.2A). Lithiophorite mosaics show different reflection (Fig. 2B). Occasionally, it is thinly banded where coarse radiating crystals are arranged in zig-saw pattern (Fig. 2C). It often occurs as dense masses of micron-sized acicular to pea shaped crystallites (Fig. 2D). It also occurs as polyhedral mosaic grains (Fig. 2E) along the periphery of vugs (Fig. 2 E \& F). Other associated Mnminerals include cryptomelane and pyrolusite. The former exhibits colloform banding while later occurs as large prismatic crystals to tiny needle shaped acicular grains. Hematite, quartz/illite form iron and gangue minerals respectively. 
Table 1: Composition of Lithiophorite and Cryptomelane phases in low-grade siliceous Mn-ore, as obtained through EPMA.

\begin{tabular}{|l|r|r|r|r|r|r|r|r|r|}
\hline & 1 & 2 & 3 & 4 & 5 & 6 & 7 & 8 & 9 \\
\hline $\mathrm{SiO}_{2}$ & 0.00 & 0.00 & 0.082 & 0.061 & 0.885 & 1.352 & 0.131 & 0.00 & 1.167 \\
\hline $\mathrm{Al}_{2} \mathrm{O}_{3}$ & 4.018 & 1.005 & 3.845 & 0.716 & 24.956 & 26.048 & 25.497 & 22.257 & 21.823 \\
\hline $\mathrm{FeO}$ & 0.098 & 0.161 & 0.118 & 0.076 & 0.16 & 0.095 & 0.176 & 0.364 & 0.176 \\
\hline $\mathrm{MgO}$ & 0.00 & 0.00 & 0.00 & 0.00 & 0.218 & 0.00 & 0.134 & 0.108 & 0.172 \\
\hline $\mathrm{MnO}$ & 69.03 & 82.43 & 81.07 & 75.39 & 50.675 & 49.74 & 53.126 & 45.529 & 43.319 \\
\hline $\mathrm{CaO}$ & 0.041 & 0.055 & 0.104 & 0.086 & 0.00 & 0.009 & 0.00 & 0.003 & 0.023 \\
\hline $\mathrm{K}_{2} \mathrm{O}$ & 2.063 & 3.73 & 3.348 & 3.12 & 0.00 & 0.002 & 0.00 & 0.048 & 0.334 \\
\hline $\mathrm{Na} 2 \mathrm{O}$ & 0.06 & 0.292 & 0.234 & 0.00 & 0.063 & 0.00 & 0.00 & 0.005 & 0.00 \\
\hline $\mathrm{TiO}_{2}$ & 0.182 & 0.099 & 0.00 & 0.017 & 0.021 & 0.019 & 0.009 & 0.00 & 0.00 \\
\hline $\mathrm{P}_{2} \mathrm{O}_{5}$ & 0.03 & 0.017 & 0.06 & 0.00 & 0.004 & 0.006 & 0.00 & 0.035 & 0.004 \\
\hline $\mathrm{NiO}$ & 0.177 & 0.00 & 0.00 & 0.00 & 0.132 & 0.057 & 0.022 & 0.127 & 1.494 \\
\hline $\mathrm{CoO}$ & 0.211 & 0.18 & 0.12 & 0.14 & 0.809 & 0.822 & 0.706 & 1.603 & 2.012 \\
\hline $\mathrm{BaO}$ & 1.263 & 0.075 & 0.501 & 0.33 & 0.00 & 0.00 & 0.00 & 0.00 & 0.029 \\
\hline $\mathrm{H}_{2} \mathrm{O}_{\odot}$ & 22.83 & 12.036 & 10.56 & 20.114 & 22.075 & 21.847 & 20.199 & 29.922 & 29.258 \\
\hline
\end{tabular}

1 to 4: Cryptomelane, 5 to 9: Lithiophorite. (C):Calculated value

\subsection{Chemical Characteristics}

The bulk sample of the siliceous manganese ore contains $26.4 \% \mathrm{Mn}, 2.78 \% \mathrm{Fe}$ and more than $32 \% \mathrm{SiO}_{2}$ (Table 2). Such low-grade manganese ore sample contains appreciable Co values ranging from $691 \mathrm{ppm}$ to $1002 \mathrm{ppm}$ (avg. $791 \mathrm{ppm}$ ) in the bulk sample. The EPMA results shown in Table 1 distinctly indicate that both lithiophorite and cryptomelane are Co-bearing. However, the lithiophorite mostly shows higher Co value than cryptomelane. Besides Co value, lithiophorite also contains appreciable $\mathrm{Ni}$ in its lattice. The X-ray image maps of $\mathrm{Mn}, \mathrm{Fe}, \mathrm{Al}, \mathrm{Si}$, $\mathrm{Co}, \mathrm{Ni}, \mathrm{K}$ and $\mathrm{Ba}$ elements in selected location (SL) occupied by lithiophorite and cryptomelane show the former phase to be rich in Co-concentration (Fig. 3). 

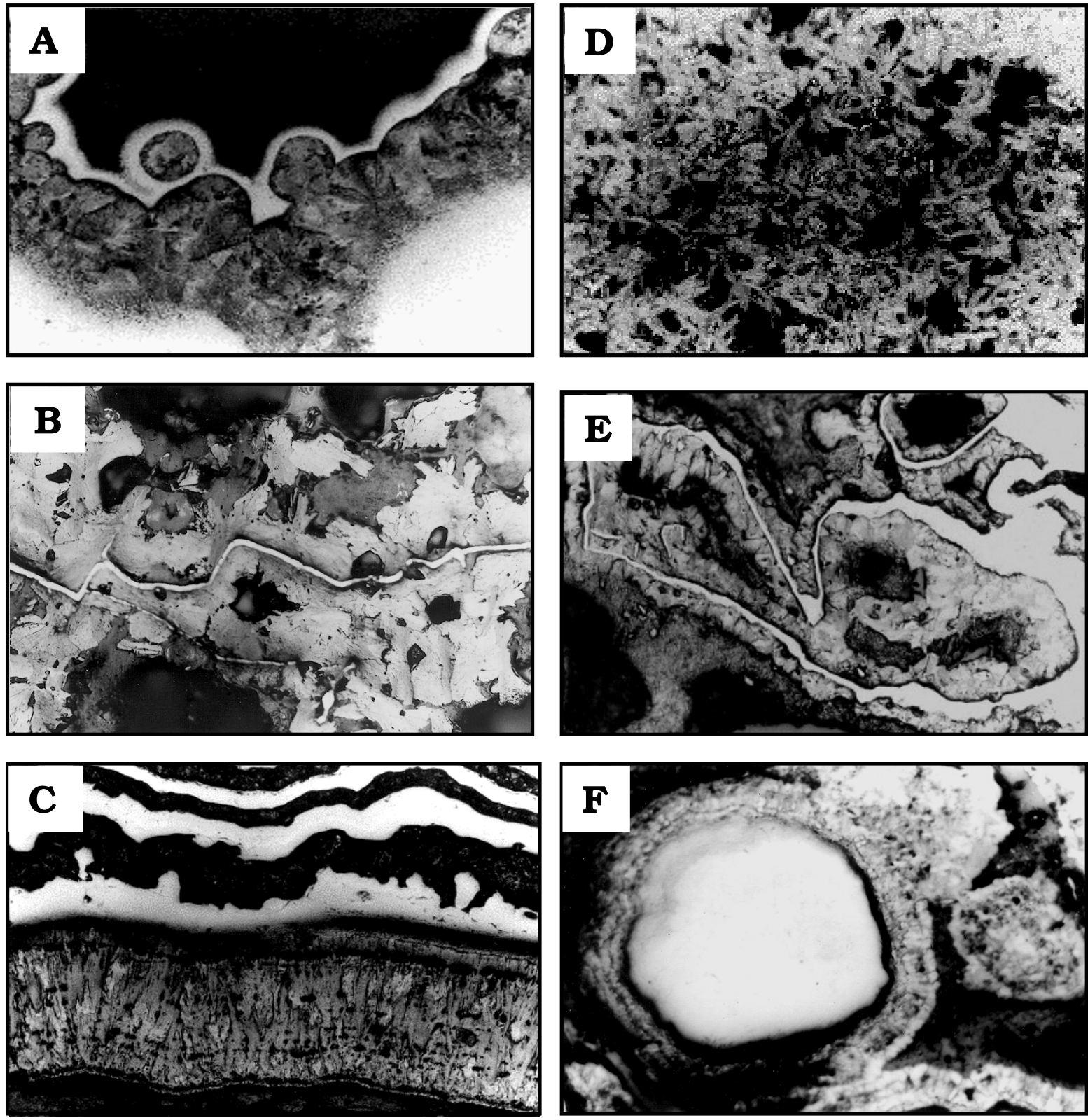

Fig 2: Photomicrograph of lithiophorite mineral showing different microstructures x200 (A) Mamillary growth of lithiphorite showing undulose segmented twinning (B) Lithiophorite mosaics showing different reflection and traversed by a cryptomelane veinlet. (C) Thinly banded, coarse grained, lithiphorite (bottom) showing zig-saw pattern. Alternate bands at the top are that of cryptomelane (white) and quartz/clay (black) D) Acicular aggregates of lithiophorite (E) Prismatic growth of lithiophorite encrusting a vug. (F) Mosaic of polyhedral crystallites of lithiophorite lining a vug. 
Table 2: Size and chemical analysis results of low-grade siliceous Mn-ore

\begin{tabular}{|c|c|c|c|c|c|}
\hline Size in $\mu \mathrm{m}$ & $\mathrm{Wt} \%$ & $\mathrm{Mn} \%$ & $\mathrm{Fe} \%$ & $\mathrm{SiO}_{2} \%$ & $\begin{array}{c}\mathrm{Co} \text { in } \\
\text { ppm }\end{array}$ \\
\hline Bulk & - & 26.41 & 2.78 & 32.42 & 791 \\
\hline+500 & 40.1 & 24.84 & 2.78 & 34.93 & 668 \\
\hline+250 & 33.4 & 25.47 & 2.92 & 33.78 & 585 \\
\hline+150 & 9.5 & 28.93 & 3.06 & 27.98 & 1002 \\
\hline+75 & 9.4 & 28.93 & 3.06 & 27.49 & 1180 \\
\hline-75 & 7.6 & 27.00 & 4.22 & 32.11 & 726 \\
\hline Head & 100 & 25.96 & 2.98 & 32.95 & 724 \\
\hline
\end{tabular}

\subsection{Beneficiation Characteristics}

In order to assess the upgradation potential and possible enrichment of manganese and other valuable traces in general and cobalt in particular, the siliceous manganese ore was subjected to physical beneficiation study. The bulk sample was crushed and subjected to sieve analysis using standard BSS sieves of 500, 250, 150 and 75 $\mu \mathrm{m}$ size. Each fraction was analyzed for Mn, Fe, $\mathrm{SiO}_{2}$ and $\mathrm{Co}$ values. The size and chemical analysis of the feed and classified fractions are presented in Table 2. The analytical results reveal that there is a marginal improvement in the Mn values through size classification. As Co is intimately associated with manganese it also shows a marginal rise.

All the classified fractions, excepting $-75 \mu \mathrm{m}$ size, were subjected to dry magnetic separation at different current intensities, viz. 10A $(0.73 \mathrm{~T}), 15 \mathrm{~A}(1.00 \mathrm{~T})$ and $20 \mathrm{~A}(1.23 \mathrm{~T})$. The classified sample below $75 \mu \mathrm{m}$ size was not processed through magnetic separator because of its low volume $(7.5 \mathrm{wt} . \%)$ in the bulk sample. Moreover, it is difficult to process $-75 \mu \mathrm{m}$ size sample through dry magnetic separator. This needs wet magnetic separation, which may not be cost effective.

The magnetic products recovered through magnetic separation in different size fractions were analyzed for Mn content. The grade and recovery of Mn-values at different magnetic intensities are given in Table-3. It can be seen from Table-3 that best grade of Mn-ore is obtained at $1.00 \mathrm{~T}$. In order to ascertain the concentration level of valuables and impurities in all the magnetic products, obtained at $1.00 \mathrm{~T}$, each fraction was analyzed for $\mathrm{Mn}, \mathrm{Fe}, \mathrm{SiO}_{2}$ and $\mathrm{Co}$. The results are presented in Table-4. A significant rise in the concentration level of manganese and cobalt values in the magnetic product with respect to the feed is noticed (Table-4). The values of Mn and Co in each fraction when plotted in a graph (Fig. 4) both were found to follow more or less a common trend line. This further substantiates the adsorption of Co values in Mn-phase. 


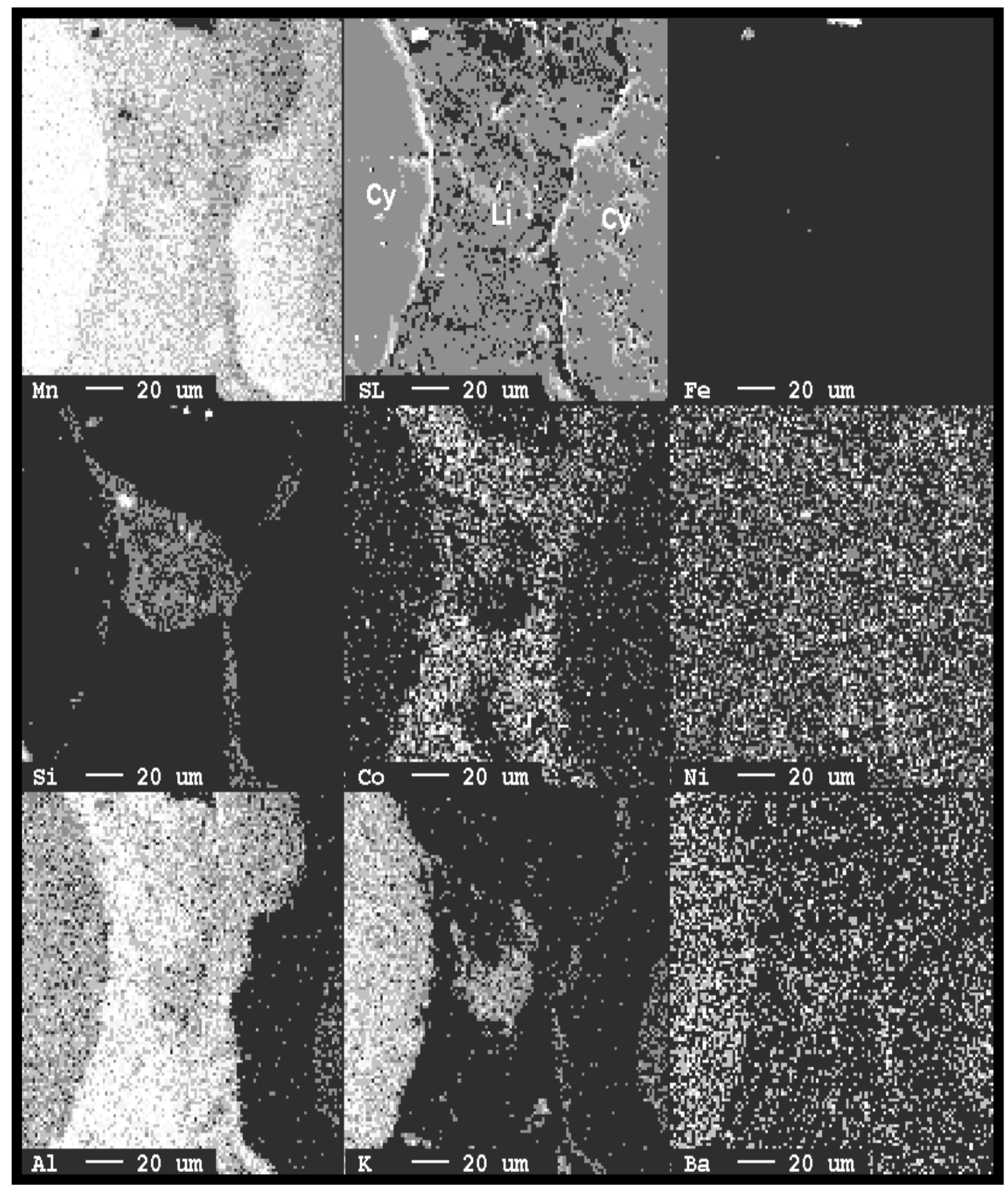

Fig. 3: X-ray image map of Manganese minerals with respect to $\mathrm{Mn}, \mathrm{Fe}, \mathrm{Si}, \mathrm{Co}, \mathrm{Ni}, \mathrm{Al}, \mathrm{K}$ and $\mathrm{Ba}$. The SL image shows the occurrence of cryptomelane (Cy) and Lithiophorite (Li).

The magnetic product so obtained at $-150+75 \mu \mathrm{m}$ size fraction at $1.00 \mathrm{~T}$ was also analyzed for other traces like $\mathrm{Li}, \mathrm{Ni}, \mathrm{Cu}, \mathrm{Zn}$ and Mo, as it showed the highest value of Mn (47.48\%, Table.4)). 
One can note from the table (Table-5) that along with $\mathrm{Co}$; some of the traces like $\mathrm{Ni}, \mathrm{Cu}$ and $\mathrm{Zn}$ also show enhancement in their values around four times than that of feed.

Table 3: Mn-value (wt. \%) and recovery (\%) in magnetic products at different size fractions and magnetic intensities

\begin{tabular}{|c|c|c|c|c|c|c|c|c|c|}
\hline & \multicolumn{3}{|c|}{$0.72 \mathrm{~T}$} & \multicolumn{3}{c|}{$1.00 \mathrm{~T}$} & \multicolumn{3}{c|}{$1.23 \mathrm{~T}$} \\
\hline Size, in $\mu \mathrm{m}$ & Wt. \% & Mn \% & $\begin{array}{c}\text { Mn \% } \\
\text { recovery }\end{array}$ & $\begin{array}{c}\text { Wt. } \\
\%\end{array}$ & Mn \% & $\begin{array}{c}\text { Mn \% } \\
\text { recovery }\end{array}$ & $\begin{array}{c}\text { Wt. } \\
\%\end{array}$ & $\begin{array}{c}\text { Mn } \\
\%\end{array}$ & $\begin{array}{c}\text { Mn \% } \\
\text { recovery }\end{array}$ \\
\hline$-1000+500$ & 38.8 & 41.9 & 23.9 & 39.3 & 43.51 & 26.0 & 41.9 & 42.7 & 33.9 \\
\hline$-500+250$ & 33.0 & 44.7 & 21.7 & 32.8 & 45.91 & 23.0 & 32.6 & 44.6 & 27.5 \\
\hline$-250+150$ & 14.2 & 42.9 & 8.9 & 13.8 & 45.91 & 9.7 & 12.4 & 41.5 & 9.7 \\
\hline$-150+75$ & 14.0 & 46.4 & 9.6 & 14.1 & 47.48 & 10.3 & 13.1 & 46.8 & 11.5 \\
\hline
\end{tabular}

Table 4: Size and chemical analysis results of magnetic products at $1.00 \mathrm{~T}$

\begin{tabular}{|c|c|c|c|c|c|}
\hline Size, in $\mu \mathrm{m}$ & $\mathrm{Wt}, \%$ & $\mathrm{Mn}, \%$ & $\mathrm{Fe}, \%$ & $\mathrm{SiO}_{2}, \%$ & $\mathrm{Co}, \mathrm{ppm}$ \\
\hline$-1000+500$ & 39.3 & 43.51 & 4.45 & 8.01 & 2956 \\
\hline$-500+250$ & 32.8 & 45.91 & 5.78 & 3.45 & 2894 \\
\hline$-250+150$ & 13.8 & 45.91 & 5.01 & 3.68 & 3658 \\
\hline$-150+75$ & 14.1 & 47.48 & 4.73 & 2.31 & 3843 \\
\hline
\end{tabular}

Table 5: Concentration level of selected trace elements in feed and best enriched product

\begin{tabular}{|c|c|c|}
\hline & & $\begin{array}{c}\text { Enriched }(-150+75 \mu \mathrm{m}, \\
1.00 \mathrm{~T})\end{array}$ \\
\hline Element in ppm & Feed & 250 \\
\hline $\mathrm{Ci}$ & 105 & 3843 \\
\hline $\mathrm{Ni}$ & 791 & 1546 \\
\hline $\mathrm{Cu}$ & 437 & 1557 \\
\hline $\mathrm{Zn}$ & 423 & 961 \\
\hline $\mathrm{Mo}$ & 170 & 23.4 \\
\hline
\end{tabular}



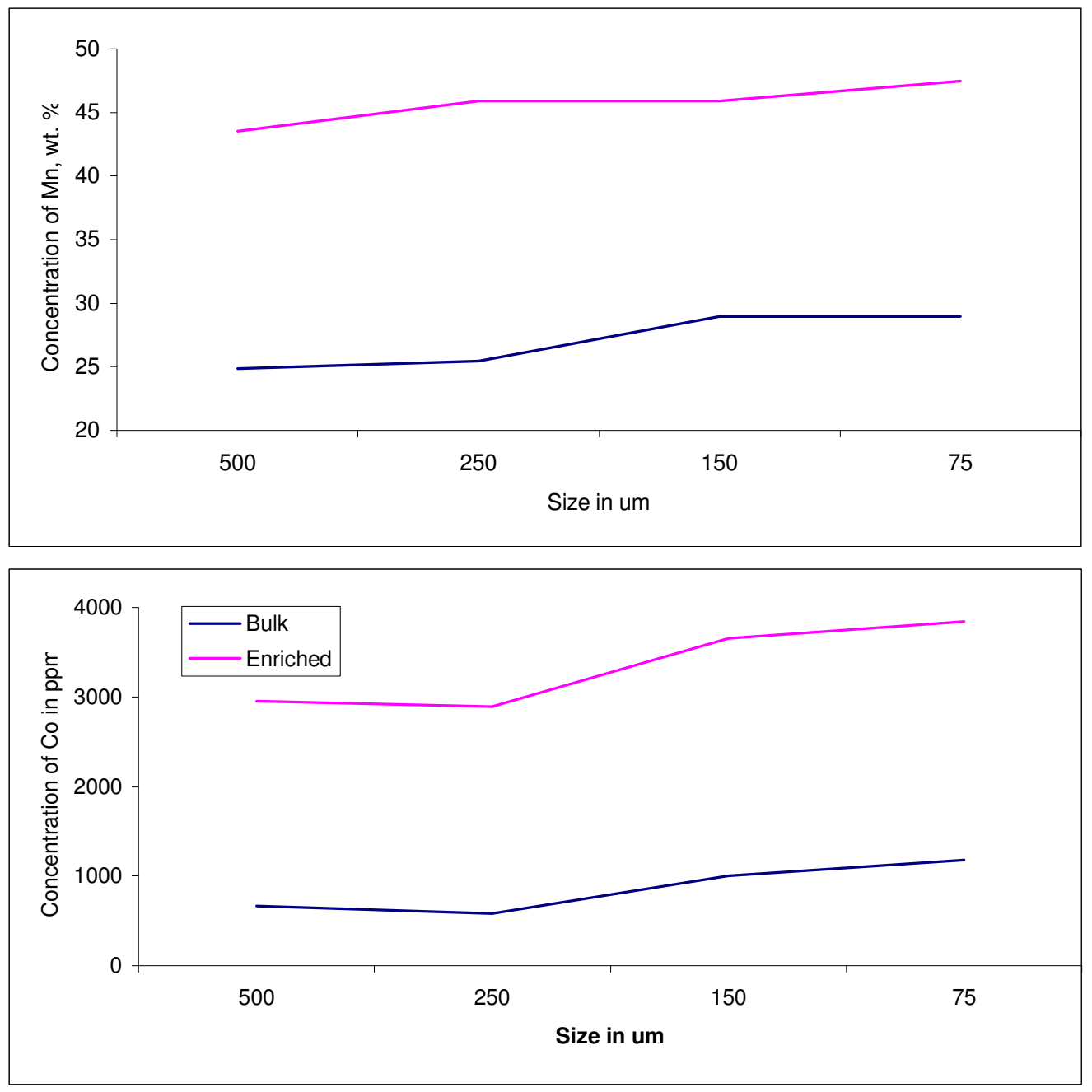

Fig. 4: Schematic diagram showing the distribution pattern of $\mathrm{Mn}$ and Co in bulk and enriched products

The beneficiation studies thus revealed that the low-grade siliceous manganese ores of BonaiKeonjhar belt, Orissa are amenable to upgradation and better utilization through a simple means of dry magnetic separation. Enrichment of Mn content from a feed of $26 \%$ to more than $47 \%$ in processed product $(-150+75 \mu \mathrm{m}$ size fraction at $1.00 \mathrm{~T})$ is definitely a significant achievement. Enrichment of Mn-content by wet high intensity magnetic separation and dry magnetic separation from Chikla manganese ore, India has also been reported by Mohapatra et. al., [9] and Rao et al., [10], respectively. However, enrichment of Co-values with that of $\mathrm{Mn}$ is reported here. A cobalt value of $791 \mathrm{ppm}$ in the Mn-ore feed can be upgraded to an average value of 3157 ppm through simple magnetic separation technique. 


\section{DISCUSSION}

Mineralogical and geochemical characterization of low-grade siliceous manganese ores from Bonai-Keonjhar belt indicated that lithiophorite is the dominant Mn-mineral and quartz is the major gangue. The electron probe microanalysis and X-ray image map of different elements in such an ore clearly reveal that the lithiophorite is cobalt bearing i.e. Co is present in adsorbed state within Mn-phase. The manganese minerals are para-magnetic in nature while quartz is nonmagnetic. So the undesired non-magnetic quartz can easily be separated from magnetic manganese phase by simple physical separation process (dry magnetic separation). Thus the trace elements in general and Co in particular present in the lattices of Mn-minerals are upgraded automatically along with the Mn-values. A four-fold increase in the cobalt and other trace values $(\mathrm{Ni}, \mathrm{Cu} \& \mathrm{Zn})$ has been recorded in the enriched product with respect to the feed sample. Following the above simple flow sheet, the low-grade manganese ore $(26 \% \mathrm{Mn})$, which has negligible market value, can be upgraded to a valuable product $(>47 \% \mathrm{Mn})$. Co enrichment further adds to the value.

Methods have been developed to recover $\mathrm{Co}$ and $\mathrm{Ni}$ metals associated with marine manganese nodules [11-13] by different leaching processes. Applicability of this method to the Orissa manganese ores needs to be studied. If 50, 000 tonnes of manganese ores with $0.5 \%$ of cobalt on an average is smelted electrically, about 250 tonnes of cobalt will be obtained. In view of advantage of recovering $\mathrm{Co}$ as a by-product with electro-manganese and the availability of substantial resources of low-grade siliceous manganese ores in Orissa, the feasibility of conversion of a part of manganese ore from this part of India deserves further detail study.

\section{CONCLUSION}

The occurrence of Co with lithiophorite phase in the low-grade siliceous manganese ores of Bonai-Keonjhar belt and their amenability to upgradation through dry magnetic separation is reported. A low-grade siliceous ore containing $26 \% \mathrm{Mn}$ and $791 \mathrm{ppm}$ Co can be enriched up to a product of $47 \% \mathrm{Mn}$ and $3843 \mathrm{ppm}$ Co with $69 \%$ recovery. Thus a waste can be converted to a wealth at very low cost and minimum unit operations. Sincere efforts are needed to recover these two valuable metals by suitable extractive metallurgical methods like chemical, bio-chemical, biological, electro-metallurgical and hydro-metallurgical process routes.

\section{ACKNOWLEDGEMENT}

The authors are highly thankful to the Director, Institute of Minerals and Materials Technology, Bhubaneswar for his kind permission to publish this paper. Thanks are due to Mr. P.S.R. Reddy, Sct. G for his critical review of the manuscript and Dr. S. Prakash, Sr. Sct. for his assistance in magnetic separation work. The authors are also thankful to the Department of Science \& 
Technology, New Delhi, India for their financial support in the form of a project (ESS/23/VES/043/99).

\section{REFERENCES}

[1] Glasby, G. P., 1975, "Minor element enrichment in manganese nodules relative to sea-water and marine sediment." Nature wissenschaften, Vol. 65, pp. 133-135.

[2] Glasby, G. P., Keays, R. R., and Rankin, P. C., 1978, “The distribution of rare earth, precious metal and other trace elements in recent and fossil deep sea manganese nodules." Geochem. J., Vol. 12, pp. 229-248.

[3] Mohapatra, B. K. and Sahoo. R. K., 1999, "Characterisation of marine ferromanganese concretions." Metals Materials and Processes, Vol. 11, pp. 101-116.

[4] Delian Fan, Hein James R., and Ye Jie, 1999, "Ordovician reef hosted Jiaodingshan Mn-Co deposit and Dawashan Mn deposit, Sichuan Province, China." Ore Geology Review, Vol. 15, pp. 135-151.

[5] Tetsuo, Yamazaki, 1999, "Cobalt rich Mn deposit and techniques required for the development.” Kagaku Kogyo, Vol. 50, pp. 372-378.

[6] Roy, S., 1981, Manganese deposits, Academy Press, London, pp. 451.

[7] Mohapatra, B. K., Paul, A. K. and Sahoo, R. K., 1989, "Characterisation of manganese ores of a part of Western Koira valley, Keonjhar Dist., Orissa." Journal of Geological Society of India, Vol. 34, pp. 632-646.

[8] Balaram, V., Manikyamba, C., Ramesh, S. L., and Saxena, V. C., 1989, "Determination of rare earth elements in Japanese rock standards by Inductively Coupled Plasma Mass Spectrometry." Atomic Spectroscopy, Vol. 2, pp. 19-23.

[9] Mohapatra, B. K; Rao, D. S. and Sahoo, R. K, 1995, "Characterisation and magnetic separation studies of Chikla manganese ores, Maharastra." Ind. Min. Eng. J., July, pp. 37-41.

[10] Rao, G. V; Mohapatra, B. K and Tripathy, A. K., 1998, "Enrichment of the manganese content by wet high intensity magnetic separation from chikla manganese ore, India." Magnetic and Electrical Separation, Vol. 9, pp. 69-82.

[11] Mohanty, P. S.; Ghosh, M. K.; Anand, S. and Das, R. P., 1994, "Leaching of manganese nodules in ammoniacal medium with elemental sulphur as reductant." Trans. Instn. Min. Met., Sec. C, Vol. 143, pp. 151-155.

[12] Devi. N. B.; Nathsarma, K. C. and Chakraborty, V., 1998, "Separation of cobalt (II) and nickel (II) from sulphate solutions using sodium salts of D2EHPA, PC88A and Cyanex 272." Hydrometallurgy, Vol. 49, pp. 47-61.

[13] Devi. N. B.; Nathsarma, K. C. and Chakraborty, V., 2000, "Separation of divalent manganese and cobalt ions from sulphate solutions using sodium salts of D2EHPA, PC88A and Cyanex 272.” Hydrometallurgy, Vol. 54, pp. 117-131. 